\title{
Historiografija srednjovjekovnog plesa mrtvaca $u$ europskom kontekstu
}

\author{
Mirela Lenković*
}

\begin{abstract}
Sažetak
Ples mrtvaca u srednjem vijeku prikazivan je u mnogim sakralnim zdanjima, a neka čine važan dio kasnosrednjovjekovnog europskog likovnog nasljeđa. Možemo ga promatrati i kao izraz koji simbolički sjedinjuje svjetovno i religijsko, a tematski u sebi nosi poruku jednakosti među ljudima, neovisno o njihovu staležu. Srednjovjekovlje je obilježeno pandemijom kuge, nedaćama i ratovima, što utječe na kulturno stvaralaštvo. Različita istraživanja (arheološka, medicinska i dr.) proučavaju etiologiju Crne smrti, evoluciju razvoja, povijest, pojavu i širenje kuge u Europi tog doba. Pojedina literarna djela (De contemptu mundi; De miseria humane conditions Innocenta III.), artes morendi, memento mori (Hélinand de Froidmont, Les Vers de la Mort) koriste se kao predlošci za likovnu izvedbu teme plesa mrtvaca.
\end{abstract}

Ključne riječi: srednjovjekovlje; ikonografija smrti; kuga u Europi; ples mrtvaca

\section{Uvod}

Ples mrtvaca kao jedan od glavnih motiva u likovnom stvaralaštvu proširio se u Europi tijekom 15. stoljeća od Francuske do Njemačke, Engleske, Skandinavije, Poljske, Španjolske, Italije, sve do Hrvatske i Slovenije. Prikazivan je u mnogim europskim sakralnim zdanjima, ali usprkos tomu teže ga je razlučiti jer u svojim temeljnim scenama miješa različite metaforičke iskaze poput plesa, dijaloga i posrednog nasilja. Ciljano stremi tomu da promatrača ili čitatelja suoči s vlastitim samoispitivanjem i poimanjem života, vjere, svakodnevice i jednakosti svih ljudi u trenutku smrti, neovisno o njihovu staležu i dobi. Važnost sinteze u povezanosti suprotnosti života i smrti, s emotivnim poniranjem ili duhovnim uzdizanjem pojedinca u rajski život nakon smrti, često je bila u mislima pojedinaca. Iznenađenje i nepredvidivost trenutka umiranja obilježja su koja se događaju u

* Mirela Lenković, doktorandica na Hrvatskim studijima Sveučilišta u Zagrebu. Adresa: Borongajska cesta 83d, 10000 Zagreb, Hrvatska. ORCID iD: https://orcid.org/0000-0003-0826-584X. E-adresa:lenkovicmirela@gmail.com 
primarnosti elemenata prirode. Metaforički prikazi smrti koja u liku kostura vodi žive na onaj svijet, osvajali su maštu ondašnjeg promatrača.

Duhovnost izražena slikama na zidovima sakralnih građevina primarno prenosi religijska i vjerska obilježja, ali i mističnost karaktera snažnih prirodnih elemenata, te od formalnog upućuju promatrača prema moralnomu i duhovnosti. No u svojoj naivnosti i neznanju čitanja pisanih tekstova u to doba, svaki vjernik imao je duhovno iznenađenje i neočekivanost percepcije zgusnute na samo jedan intenzivan trenutak - trenutak ulaska u sakralni prostor, svijet interijera koji je težio jednomu i jedinstvenomu širenju Božje riječi i postulata Biblije, gdje je zapisano: »Zaista, zaista, kažem vam, tko sluša moju riječ i vjeruje onomu koji me posla, ima život vječni i ne dolazi na sud, nego je prešao iz smrti u život. Zaista, zaista, kažem vam: dolazi čas — sada je! — kad će mrtvi čuti glas Sina Božjega i koji čuju, živjet će« (Iv 5,24-25).

Srednjovjekovnomu čovjeku na vizualan su se način, tj. slikama i kipovima, iskazivali različiti postulati i vjerske intencije koje su ti radovi (naručeni od crkvenih naručitelja) trebali postići. Huzinga piše: "Velikim događajima: rađanju, sklapanju braka, umiranju davao je sakrament sjaj božanskog misterija. Ali su i manje važna zbivanja, kao što su neko putovanje, neki rad, neki posjet, popratile tisuće oblika ophođenja, blagoslova, ceremonija i uzrečica."1 »U svakoj kulturi koncepcija se svijeta iskazuje stanovitim brojem slika, koje se javljaju u specifičnom obliku i imaju sebi svojstven duhovni bitak «. ${ }^{2}$ Čitanje slika posredstvom predstavljenih ikonografskih tipova i ovisnost o tradicijskoj zaokupljenosti stila, postavke su po kojima je tadašnji promatrač u vlastitoj složenosti procesa opažanja trebao vidjeti predočeno i doživjeti poruku koju ona iskazuje.

\section{Historiografija povijesti kuge u srednjem vijeku na području Europe}

Srednjovjekovno razdoblje bilo je obilježeno pandemijom kuge, nesrećama, sušama, nevremenima i ratovima, pri čemu su te nedaće inspirirale pjesništvo, glazbu i likovno stvaralaštvo. Praznovjerje i strahovi bili su svakodnevica ljudi, a kuga, bolesti i infekcije dio života. Tražili su utjehu od teškog života u vjeri, koja im je obećavala zagrobni život i oslobođenje od vječne patnje što ih je okruživala. Vjerovanje da je ovozemaljski život samo razdoblje priprema za vječni život, te

1 Nizozemski povjesničar umjetnosti Johan Huizinga (1872.-1945.) u knjizi Jesen srednjeg vijeka (1919.) razmatra svakodnevicu srednjovjekovlja i prikaze u književnosti i umjetnosti. (Huizinga, 1991, 3)

2 Białostocki objašnjava i proširuje teze preuzete iz Huizingina poglavlja Kleines Gespräch über die Themen der Romantik (Huizinga, 1930, 378-390), te citira teze u kojima se prema Huizingi likovi kao što su kralj, sudac, seljak, vrline, godišnja doba i dr. ne poimaju kao intelektualne jedinke, nego su oblikovani gotovo kao numina (snage Božje prirode). Naglašava da u davnim stilovima umjetnosti svaka od tih tema služi izražavanju i prihvaćanju temeljne misli u kojoj je sadržan čitav stil (u skulpturi katedrala, riječima skolastike i sl.). Objašnjava da su one usmjerene prema središnjemu načelu kulture kojoj služe, te odaju počast njezinim tezama i vrijednostima te o njoj svjedoče (Białostocki, 1986, 110). 
da tijelo ne treba razmaziti pojedinim zemaljskim užicima ${ }^{3}$ bilo je uobičajeno. Teški životni uvjeti i nedostatak higijene bili su pogodno tlo za raznovrsne i mnogobrojne epidemije. Različite bolesti i komplikacije od fizičkih povreda (infekcija) smatrane su nebeskom kaznom za grijehe pojedinaca.

Stoljećima je racionalni medicinski pristup Hipokrata bio zanemaren, često potisnut neukošću i praznovjerjem. U prakticiranju medicine često su rituali i praznovjerje preuzeli ulogu dijagnoze i liječenja. Različiti putopisci s istoka opisuju uvjete života u ondašnjim europskim gradovima kao izuzetno teške. Nečistoća, zagađenost vode za piće, prevelik broj stanovnika u pojedinim gradskim središtima i siromaštvo samo su neki od podataka koje nam usputno navode tadašnji putopisci kao autentični kroničari svojeg doba. Pojedini likovni primjeri (primjerice slikarstvo), ako se izuzmu stilske karakteristike u umjetnosti, prikazuju ljude kao iznimno blijede (pokazatelji anemije, bolesti), mršave, pothranjene i izmučene bolešću, te oni također jednim dijelom vizualno dokumentiraju socijalne prilike života.

Epidemije poput kuge, ${ }^{4}$ koje su se javile u nekoliko razdoblja tijekom povijesti, opustošile su mnoge regije i gradove Europe u srednjem vijeku. Po nekim procjenama pučanstvo se smanjilo za dvije trećine. Crna smrt, tzv. Druga pandemija ${ }^{5}$ bila je na vrhuncu u 14. stoljeću, a završila je krajem 17. stoljeća. Suvremena istraživanja ${ }^{6}$ poput arheoloških i medicinskih istražuju etiologiju Crne smrti i evoluciju razvoja uzročnika kuge te njezino širenje tijekom srednjeg vijeka u različitim dijelovima Europe (Haensch i dr., 2010).

Različiti izvori opisuju kako je kuga došla iz luke Caffa (Dauber Jones, 1979, 54) na Levantu 1347. te slijedila trgovačke rute prema Europi (Wheelis, 2002). Tijekom 1346. u Europi je bilo poznato da je kuga zahvatila mongolske zemlje u prednjoj Aziji. Navedeno područje tada je imalo ustaljene trgovačke ekspoziture i rute koje su vodile prema europskim gradovima. Jedna od njih bila je i Caffa na poluotoku Krimu (sadašnja Feodozija u Ukrajini). Caffa je bila talijanska luka, osnovana od strane Genove 1266. sporazumom s mongolskim kanom. Kao glavna luka namijenjena velikim trgovačkim genoveškim brodovima, bila je povezana i s Tanom (današnji Azov u Rusiji) na rijeci Donu. Trgovina duž rijeke Don povezivala je Tanu u centralnoj Rusiji, a do Dalekog istoka vodili su kopneni putevi.

3 U to se ubrajala i higijena tijela, poput pranja (Dauber Jones, 1979, 54).

4 Kuga (lat. pestis) jedna je od najopasnijih zaraznih, akutnih i epidemijskih bolesti. Bolest je poznata više tisuća godina, njezin uzročnik Yersinia pestis (nekadašnji naziv Pasteurella pestis) otkriven je tek krajem 19. stoljeća. Širi ju štakorska buha, primarno među glodavcima, ali i na ljude. Postiji niz medicinskih istraživanja o uzročnicima širenja kuge tijekom stoljeća, vrstama parazita itd.

5 Pandemije kuge javile su se u tri navrata. U antici epidemija kuge vladala je u 6. st., zatim u srednjem vijeku, kada se javila sredinom 11. stoljeću u Mezopotamiji, pri čemu je uzrokovala Crnu smrt u Europi i naknadne epidemije tijekom tog drugog vala, te treći val tzv. Orijentalni, koji uzrokuje suvremne pojave te bolesti. O procesu širenja kuge u povijesnim okvirima te o medicinskim istraživanjima usp. Achtman i dr., 1999.

6 Pojedina istraživanja proučavaju razvoj širenja kuge, uzročnike u Europi od 1347. do 1750. i različite lokalitete. 
Prema povijesnim podatcima, mongolski su ratnici 1346. opsjedali Caffu. Mongoli su bili prisiljeni povući se, a među njima je vladala kuga. Prije povlačenja u zatvoreni su grad katapultima bacali zaražena tijela, a mrtva tijela stanovnici grada bacali su u more. Genovežani su svjesni ratne opasnosti odlučili napustiti grad, koji je u međuvremenu bio zaražen kugom, čega nisu bili ni svjesni. Preživjeli su stanovnici Caffe bježeći prenijeli kugu u Europu (Wheelis, 2002).

Po nekim izvorima u sicilijansku je luku Messina uplovilo 12 brodova u kojima je bilo mnoštvo mrtvih mornara, a malobrojni preživjeli putnici bili su u teškom stanju zaraženi kugom. Sicilijanske vlasti naredile su da brodovi napuste luku, ali bilo je prekasno, bolest se proširila te u roku nekoliko godina zavladala Europom. U kratkom razdoblju od 1346. do 1351. brzo se proširila i tako dobila naziv Crna smrt. Sporadično se pojavljivala još 300 godina. Širila se ugrizom buhe sa štakora i poharala sela, gradove i regije. Neki liječnici tog doba ostavili su arhivske zapise u kojima opisuju različite oblike kuge, često savjetujući da se brzo napusti grad (Dauber Jones, 1979, 55).

Prateći historiografiju i tematiku srednjovjekovne povijesti bolesti, kuga je svojom pojavom i razvojem učinila neposredan utjecaj na svakodnevni život, a posebno se to izražavalo u umjetnosti, filozofiji, književnosti i glazbi (Ravančić, 2007). Boccaccio u Decameronu započinje pripovijedanje realističnim opisom pošasti kuge u Firenzi 1348. godine: »Velim dakle da su godine od plodonosnog Utjelovljenja sina Božjeg brojem do tisuću tristo četrdeset i osme stigle, kad je dični grad Firenzu [...] pohodila smrtonosna kuga, koja se, ili zbog djelovanja nebeskih tijela ili zato što je zbog naših zlih djela pravedan gnjev Božji posla na smrtnike da ih popravi, [...] prelazeći iz mjesta u mjesto bez prestanka prema Zapadu nevoljno širila« (Boccaccio, 2004, 10-13).

\section{Tema smrti u srednjovjekovnim literarnim djelima}

Ples mrtvaca obuhvaća vrlo opsežan opus različitih podataka, a u slučaju da se likovnosti pridodaju različite dodirne točke iz područja srednjovjekovne glazbe ili književnosti, tada ona tematski zahtijeva posebnu pažnju. Oblik povijesti smrti javlja se i ranije tijekom stoljeća u drugačijim oblicima. ${ }^{7} \mathrm{U}$ srednjem vijeku u Europi vrlo su raširene teme motiva smrti i plesa mrtvaca, te postoji bogata

7 Primjerice, početci oplakivanja mrtvih mogu se naći kod navodnog prvog ljudskog ukopa, Sima de los Huesos, Homo Heidelbergensis, Atapuerca, Španjolska. Nalazi u tzv. Špilji kostiju (Sima de los Huesos) obuhvaćaju posmrtne ostatke 30 pojedinaca Homo Heidelbergensis, uz koje je ostavljen pribor za koji se smatra da je grobni dar. Izložba nalaza održana je u Musée de l'Homme à Paris 2009. godine. Tema smrti koja se proteže od antike (mauzoleji), zatim starog Egipta (piramide), kasnijih razdoblja, kao i različiti primjeri izraženi na polju likovnosti u Europi sadržava različite prikaze smrti, umiranja i života nakon smrti. Izvan granica europskog kontinenta, na području američkog kontinenta, u SAD-u, a posebno u Meksiku, specifična su tema načini na koji se u kršćanskoj religiji dočekuje Dan mrtvih i kako se on posvećuje pokojnima (o čemu postoji cijeli niz različitih studija). Neophodno ih je makar samo i spomenuti, da se vidi široki opseg teme smrti, koja često nosi u sebi glavnu misao — da smrt nije kraj, nego početak nekog drugog života. Kršćanstvo to posebice posredstvom biblijskih tekstova lijepo opisuje. 
likovna ostavština. Ratovi, različite bolesti poput kuge i nedostatak medicinskog znanja učinili su da se senzibilizira ljudska svijest o lakoći umiranja, ${ }^{8}$ a prizori smrti postali su dio svakodnevice. Srednjovjekovni čovjek i svece vidi kao pojedince koji su u jednostavnosti života dosegnuli neprobojnost vjere, dok ih gledaju na oslikanim prikazima ili kipovima u impozantnosti sakralnih objekata. Mora se napomenuti da pojedine građevine koje su zidane desetljećima, ostavljaju jak dojam na tadašnjeg promatrača. U tom kontekstu možemo sagledati i scene plesa mrtvaca koje uvode žive u svijet mrtvih, jer smrt ne zaobilazi nikoga.

Neophodno je spomenuti pojedina literarna djela nastala u 12. stoljeću, radove kao što su De contemptu mundi i vrlo tada popularan De miseria humane conditions Innocenta III. (Dunne, 2007). U njima se može naći početak dugačke tradicije tekstova na temu artes moriendi. ${ }^{9}$ Rani literarni primjer memento mori napisao je primjerice Hélinand de Froidmont ${ }^{10}$ u spjevu Les Vers de la Mort između 1194. i 1197. (a kasnije ju se gleda kao dio tradicije plesa mrtvaca) (Dunne, 2007). Hélinand piše o smrti koja posjećuje različite pojedince i obavještava ih da će jednom umrijeti. Budući da oni ne znaju kada će se to dogoditi, trebaju se pripremiti nakon različitih životnih priča punih vrlina (Espí Forcén, 2013). Stihovi također naglašavaju kako će smrt dostignuti svakoga, neovisno o tome koliko je netko bogat ili moćan, jer svatko naposljetku umre. Hélinand razvija svoj rad oko tri teme: smrti koja pristiže uskoro, potrebu da se distancira od ovozemaljskih dobara i ljudske sudbine u sljedećem životu. Sljedeći stihovi to opisuju:

Morz, toi suelent cremir li sage:
Or queurt chascuns a son damage:
Qui n'i puet avenir s'i rue.
Por ce ai changié mon corage
Et ai laissé et gieu et rage

O Death, those who are wise have always feared you

Now, however, everyone rushes to their destruction

And if they do not meet you at the pass, you gallop towards them.

For this reason, I changed my ways

And left behind pleasure and madness

(Dunne, 2007, 2)

8 Smrtnost je bila više nego sveprisutna zbog bolesti poput bubonske kuge, tzv. Crne smrti u Europi, koja je uzrokovala smrtnost gotovo pola europskog stanovništva u periodu između 1348. i 1350. godine (Espí Forcén, 2013, 10-12).

9 Ars moriendi, dva su povezana latinska teksta koji su nastali oko 1415. i 1450, a nude savjete i procedure tzv. dobre smrti, objašnjavajući kako "dobro umrijeti” sukladno pogledima na svijet u srednjem vijeku i postulatima kršćanske vjere. Pisana je u povijesnom kontekstu velikih stradanja od kuge ranijih razdoblja i velikih socijalnih prevrata na povijesnoj sceni (Blake, 1983, 547-548).

10 Hélinand de Froidmont (1160.-1237.), srednjovjekovni pjesnik, kroničar i eklektički pisac. Rođen je u Francuskoj, od roditelja flamanskog podrijetla. Nakon svjetovnog života, napušta francuski dvor, zaređen je te ulazi u red cistercita 1190. u samostan Diocèse de Beauvais, Francuska (Elder, 2013, 207-208). 
Za razliku od kasnijih autora, on ne uključuje macabre, te apelira na um i emocije svojih čitatelja (slušatelja), naglašavajući im da se ne boje. ${ }^{11}$ Poeme Vado mori također su bitne za temu plesa mrtvaca u umjetnosti. Svaka strofa počinje i završava izrazom: "Ja ću umrijeti". Ako se gleda tekst Biblije, tada se zamjećuje da se odricanjem od ovozemaljskih dobara, okretanjem na pravi put i poštivanjem Božje riječi pojedinac ne mora bojati smrti. Naglašava se važnost krštenja, smrti, uskrsnuća i novog života, poput primjerice: »Što ćemo dakle reći? Da ostanemo u grijehu da milost izobiluje? Nipošto! Jednom umrli grijehu, kako da još živimo u njemu? Ili zar ne znate: koji smo god kršteni u Krista Isusa, u smrt smo njegovu kršteni. Krštenjem smo dakle zajedno s njime ukopani u smrt da kao što Krist slavom Očevom bi uskrišen od mrtvih, i mi tako hodimo u novosti života« (Rim 6,1-4).

Smrt koja je u razdoblju srednjeg vijeka bila posvuda sveprisutna, ne pojavljuje se samo u literarnim predlošcima, nego se sukcesivno javlja širom Europe u umjetnosti. Za kršćanstvo je neizmjerno važna pisana riječ, a širenje vjere čitanjem biblijskih tekstova, slušanjem misa i propovijedi u različitim sakralnim objektima i samostanskim centrima bilo je od iznimne važnosti. Božje riječi naglašavaju i biblijski tekstovi poput evanđelja, gdje se iskazuje upravo jedan od glavnih postulata kršćanstva: »U početku bijaše Riječ, i Riječ bijaše u Boga i Riječ bijaše Bog. Ona bijaše u početku u Boga. Sve postade po njoj i bez nje ne postade ništa. Svemu što postade u njoj bijaše život i život bijaše ljudima svjetlo; i svjetlo u tami svijetli i tama ga ne obuze. Bi čovjek poslan od Boga, ime mu Ivan« (Iv 1,1-6).

Budući da mnogi srednjovjekovni ljudi ipak nisu znali čitati, zato su im Božja riječ i Biblija približeni slikovnim putem, tj. umjetnošću. Mnogobrojni likovni umjetnici, kao što su slikari, kipari, arhitekti, pa i samouki autori, zatim drvodjelje ili štukateri, stvarali su djela koja su se kroz povijest očuvala. Ti radovi danas tvore kulturnu baštinu pojedinih sredina u Europi i Hrvatskoj. Majstori su često koristili i različite vizualne predloške pri izradi biblijskih motiva, ovisno o željama crkvenih ili gradskih naručitelja, te su time doprinosili i vjerskomu educiranju pučanstva i propagiranju postulata kršćanstva. No srednjovjekovni čovjek nikako nije mogao biti imun na sva zbivanja koja su ga okruživala. Primjer je toga i ulazak tadašnjih suvremenih tema i problematike poput motiva smrti u temi plesa mrtvaca na crkvene zidove. Širom Europe ta tematika se javila u različitim državama, primjerice u Francuskoj, Njemačkoj, Švicarskoj, Italiji, Engleskoj i dr., te je stigla u današnju Hrvatsku, tj. Istru, čime naše područje prati suvremena likovna zbivanja u europskom kontekstu. Istarski ples mrtvaca nalazi se u Beramu, gdje je unutrašnjost crkve sv. Marija na Škrilinah oslikana freskama (nastale 1474.) na 46 oslikanih polja, s temama iz Marijina i Isusova života. Ime majstora Vincenta iz Kastva zapisano je na južnom zidu iznad bočnih vrata. Osim njega na freskama su radila još dva majstora, tzv. Majstor Plesa Mrtvaca i Majstor Pasije (Fučić, 1992, 110-111). Bitno ih je spomenuti da se vidi simultanost zbivanja na našem području u odnosu na Europu.

11 Pojava kuge u kasnijim razdobljima naspram smrti evocira različite osjećaje zbog širenja bolesti. No autor ih ne implicira, nego naglašava upravo odsustvo straha (Dunne, 2007). 


\section{Ples mrtvaca na području Europe}

Najstariji primjeri plesa mrtvaca na području Europe datiraju u razdoblje oko 1400. do 1420. godine, no veći dio stručnjaka smatra da je vjerojatno bilo i ranijih primjera, jer se oni opisuju u različitim tekstovima. Komparacijom tekstualnih podataka iz različitih rukopisa i onoga što se danas zatječe na terenu dobiva se potpuna slika i odgovor na pitanja o izboru tema na mjestima gdje se javljaju, stilskim obilježjima, odabiru prikazanih likova, kao i utjecaju pisanih dokumenta, tadašnje književnosti i biblijskim predlošcima.

U Francuskoj najraniji primjer dance macabre ili plesa mrtvaca potječe iz 1424. godine. Freska s motivima plesa mrtvaca bila je naslikana na vanjskim zidovima groblja crkve Les Saintes Innocentes ${ }^{12}$ u Parizu i spominje se prvo u rukopisima koje je 1485. objavio Guyot Marchant. Iako su zidovi i slike odavno uništeni, prikazi su očuvani na Dance Macabre, tj. drvorezima koji potiču iz edicije Guyota Marchanta. Autorstvo objavljene poeme koja prati drvoreze nikada nije bilo precizno utvrđeno, ${ }^{13}$ ali pripisivana je Jeanu Gersonu (kancelaru Sorbone) (Fein, 2000, 1-11). No, ako se ne radi o Gersonu osobno, tada autor pripada tomu teološkomu krugu. Merchantova knjiga ubrzo je stekla iznimnu popularnost, a inspirirala je mnogobrojne reprintove u Parizu, Lyonu i Troyesu. Nakon originalne edicije, ubrzo je slijedila i proširena edicija, koja je objavljena 1486. godine. Postoji samo jedna kopija navedenog djela, koja se čuva u Bibliothèque Municipale u Grenobleu. ${ }^{14}$

Kasnija razdoblja u europskoj umjetnosti pružaju mnoge likovne primjere, jer se teme smrti i plesa mrtvaca javljaju na nekim mjestima i puno kasnije, ovisno o područjima (pa čak i izvan europskog kontinenta). ${ }^{15}$ Putem kopija i reprintova

12 Datira se u razdoblje oko 1424. do 1425. godine.

13 Njezina didaktičnost podsjeća na način na koji je Jean Gerson pisao propovijedi i po kojima je bio poznat.

14 Godine 1969. objavljena je kopija edicije (Pierre Vaillant, Grenoble: Editiones des 4 Seigneurs). Originalno djelo iz 15. stoljeća nalazi se u kolekciji: Collections générales, inventarni broj: I.327 Rés. Signatura autora: Marchant, Guy (14.-15.; imprimeur-libraire).

15 Nemoguće je ovdje spomenuti sve podatke poput rukopisa (koji se danas čuvaju u mnogim arhivima), kao ni priložiti različite fotopriloge arhitektonskih interijera s prikazima zidnog slikarstva i dr. No, ako se gleda puno širi kontekst, makar informativno (budući da je u ovom radu ipak težište interesa na ikonografiji u Europi), treba navesti i kasniji period otkrivanja Amerike (1492.) i osvajanja američkog kontinenta, s obzirom na to da pojedini stručnjaci pronalaze pojedine segmente preuzete upravo iz europske kulturne baštine posvećene srednjovjekovnim motivima plesa mrtvaca, no to su ipak posebne teme, koje zahtijevaju i drugačije obrade. Razlozi zašto ih se spominje, iako ovdje nisu tema, je u tome da se vidi kako su se trudom pojedinaca i crkvenih redova očuvali i sačuvali različiti vidovi europskog kulturnog nasljeđa za buduće generacije. Proučavanje koliko je utjecaj plesa mrtvih posredstvom različitih načina, knjiga, rukopisa i sl. utjecao na određene ikonografske sheme i običaje na drugom kontinentu (područje sjeverne Amerike i Meksika), te eventualno stvaranje paralela simultanosti prikaza na različitim likovnim primjerima, također se jednim dijelom nadovezuju na teme srednjeg vijeka. Prilikom istraživanja primjerice načina obilježavanja dana mrtvih u Meksiku, mnogi autori osvrću se upravo na srednjovjekovnu kulturnu klimu Europe i kršćanstvo, kao i suvremene tokove umjetnosti i tradicije (Brandes, 1998, 181-218). 
mnoga djela izaslana su dalje u svijet i na područja koja su bila vrlo daleko od samog originala. Danas nam ti arhivski podatci služe kao bogat izvor informacija o zbivanjima na različitim područjima i simultanosti razvoja, ali shodno suvremenim načinima istraživanja i za komparaciju o spomeničkoj i arhivskoj baštini. ${ }^{16}$

Neki autori spominju različita istraživanja u kojima se traži podrijetlo plesa mrtvaca, proučava likovni stil i razdoblje nastanka pojedinih djela (komparirajući i crkvenu arhivsku građu), te spominju grupu djela vezanu uz španjolsko pjesništvo Danza general de La muerte, ${ }^{17}$ francuski Danse macabre, crkveno slikarstvo u opatijskoj crkvi St. Robert u La Chaise-Dieu, ${ }^{18}$ Auvergne (Francuska), kao i slike plesa mrtvaca u njemačkoj crkvi u Lübecku (Marienkirche) iz 1463. godine (Schulte, 1990, 153). Dio podataka koji se odnose na ples mrtvaca u Lübecku datiraju ga u razdoblje između 1463. i 1466. godine.

Ples mrtvaca u Lübecku uništen je u bombardiranju 1942. godine. Ciklus Oberdeutschen vierzeiligen Totentanz pisani su podatci o zidnom slikarstvu u Ulmu, Großbaselu, Kleinbaselu, Metnitzu (Kärnten) i Wylu (St. Gallen), a spominju se u rukopisima i fragmentima ranih otisaka iz tzv. schwäbisch-alemannischen područja, kako ih se naziva u njemačkoj literaturi. Najstariji rukopisi datiraju u razdoblje između 1443. i 1447. u Augsburgu, a pisani su za Margaretu od Savoya. ${ }^{19}$ Primjer plesa mrtvaca nalazi se i u berlinskoj Marinekirche, na freski iz 1484. godine. ${ }^{20}$

Primjerice, u kasnijem razdoblju ciklus plesa mrtvaca u drvorezu (1523.1526.) napravio je Hans Holbein mlađi (1497.-1543.). ${ }^{21}$ Tema plesa mrtvaca javlja se i u kasnijim stoljećima, na različitim područjima Europe, a mnoga od tih kasnijih djela koriste upravo srednjovjekovne predloške. Njemačka spomenička baština s temom plesa mrtvaca obuhvaća ostavštinu u tipu zidnog slikarstva, skulptura, manuskripta i knjiga. Neki su primjerci očuvani, a drugi su ostali zabilježeni u različitim opisima u pismenim dokumentima, posredstvom crkvenih redova i njihovih arhiva.

Na području današnje Švicarske za primjer se plesa mrtvaca u literaturi (kao i u različitim švicarskim muzejskim programima) često spominje ciklus iz Basela. Pretpostavlja se da je nastanak plesa mrtvaca u dominikanskom samostanu u Baselu potaknula pojava kolere, kao i utjecaj u to vrijeme vrlo poznatog Dance macabre slikarstva pariškog groblja Aux Saints Inocents (Schulte, 1990, 162).

16 U europskom okviru kulturne ostavštine pojedinih područja, likovne umjetnosti i književnosti treba spomenuti i dokumentaciju koja se bavi pitanjima glazbe (sačuvana je u različitim oblicima arhivske građe i notnih zapisa) jer mnogi likovni prikazi plesa mrtvaca sadrže glazbala.

17 Danza general de la muerte datira se u razdoblje oko 1400., no neki ju stavljaju u 1500. godinu (Schulte, 1990, 154).

18 Polemike o njezinoj dataciji vode se kroz različitu literaturu, a odnose se na razdoblje nastanka plesa mrtvaca i neki ga smještaju u razdoblje oko 1460.-1470., a novija istraživanja spominju razdoblje od 1410 do 1420. (Schulte, 1990, 155-156).

19 Tekstovi su pisani na njemačkom i latinskom jeziku.

20 Freska je 22,6 m dugačka i 2 m visoka, a zamjećuje se utjecaj ciklusa iz Lübecka.

21 Nastalo u razdoblju od 1523. do 1526., a po nekim autorima djelo je završeno 1525. u Baselu, te objavljeno tek 1538. u Lyonu (Makenbach, 1995, 1285-1286). 
Oko 1424./25. dovršen je popularni pariški ples mrtvaca, a 1431. otvoren je Baselski koncil (1431.-1448.), čiji internacionalni karakter u krugu sudionika koncila podrazumijeva i poznavanje pariških slika. U ljeto 1439. i Basel je bio zahvaćen epidemijom kuge, što se odrazilo i na broj sudionika na Koncilu, koji je znatno smanjen. Sve su to bili preduvjeti za nastanak slika s motivom plesa mrtvaca u dominikanskom samostanu (oko 1440.), koji je u to vrijeme bio vrlo bitan, kako za grad Basel, tako i za Koncil. O različitim ranijim pisanim izvorima (na latinskom i njemačkom), zatim utjecaju pariškog plesa mrtvaca i nastanku ciklusa iz Basela vode se različite polemike (Schulte, 1990, 162-163). Šezdesetak metara dugačka zidna slika oslikana je unutar zidova groblja dominikanskog samostana. Prikazuje četrdeset mrtvih likova koji susreću Smrt. Likovi personificiraju sve dobne grupe, zanimanja i staleške pozicije (vladar, vladarica, biskup, opat, odvjetnik, liječnik, plemić, kuhar i dr.). Kada je dominikanski samostan srušen 1805., bilo je spašeno samo 19 fragmenata. ${ }^{22}$

U Europi primjere plesa mrtvaca imaju mnoge zemlje, poput Engleske, Austrije, Italije, Hrvatske, Slovenije i Španjolske, u obliku zidnog slikarstva, skulptura ili različitih manuskripta, no svaki od njih ipak zahtijeva opširan prikaz, te su stoga ovdje navedeni u kronološki Tablici 1 radi lakšeg pregleda lokaliteta, kao i njihove predmetne očuvanosti (Makenbach, 1995, 1289).

Tablica 1. Kronološki prikaz lokaliteta i očuvanosti kasnosrednjovjekovnih prikaza plesa mrtvaca prema Hammersteinu

Table 1. Chronological account of sites and preserved Late-Medieval Danse Macabre tableaux according to Hammerstein

\begin{tabular}{|c|c|c|}
\hline Lokalitet & $\begin{array}{c}\text { Godina } \\
\text { (prema Hammersteinu) }\end{array}$ & Očuvanost \\
\hline \multicolumn{3}{|l|}{ Francuska } \\
\hline \multicolumn{3}{|c|}{ Zidno slikarstvo i skulpture (A) } \\
\hline La Chaise-Dieu & Oko $1415 ?$ & $\mathrm{Da}$ \\
\hline Paris (Saints Innocents) & $1424 / 25$ & $\mathrm{Ne}$ \\
\hline Kermaria & Oko $1430 ?$ & $\mathrm{Da}$ \\
\hline Meslay-le-Grenet & Oko 1490 & $\mathrm{Da}$ \\
\hline La Ferté-Loupière & Oko 1500 & $\mathrm{Da}$ \\
\hline Kientzheim & Oko 1517 & $\mathrm{Ne}$ \\
\hline Rouen (B) & 1526 & $\mathrm{Da}$ \\
\hline \multicolumn{3}{|l|}{ Manuskripti i knjige } \\
\hline Paris (Marchant) & 1485 & $\mathrm{Da}$ \\
\hline Paris (Vérard) & Oko 1485 & $\mathrm{Da}$ \\
\hline
\end{tabular}

22 Oni danas čine osnovu prezentacije, a da se dobije što bolji dojam o izgledu tih monumentalnih prikaza danas se koriste replike svih 40 prikaza za publiku (primjerice u Historisches Museum Basel). 


\begin{tabular}{|c|c|c|}
\hline \multirow{2}{*}{\multicolumn{3}{|c|}{$\begin{array}{l}\text { Njemačka } \\
\text { Zidno slikarstvo i sklupture (A) }\end{array}$}} \\
\hline & & \\
\hline Ulm & 1440 & $\mathrm{Ne}$ \\
\hline Lübeck (Marienkirche) & 1466 & $\mathrm{Ne}$ \\
\hline Berlin & Oko 1485 & $\mathrm{Da}$ \\
\hline Dresden (B) & $1534 / 37$ & $\mathrm{Da}$ \\
\hline \multicolumn{3}{|l|}{ Manuskripti i knjige } \\
\hline Codex palatinus & Oko $1350 ?$ & $\mathrm{Da}$ \\
\hline Heidelberger Blockbuch & Oko 1465 & $\mathrm{Da}$ \\
\hline Handschrift Kassel & Oko 1470 & $\mathrm{Da}$ \\
\hline Knoblochtzer Druck & Oko 1485 & $\mathrm{Da}$ \\
\hline Lübecker Druck & 1496 & $\mathrm{Da}$ \\
\hline Handschrift Zimmern & Oko 1520 & $\mathrm{Da}$ \\
\hline \multicolumn{3}{|l|}{ Švicarska } \\
\hline \multicolumn{3}{|l|}{ Zidno slikarstvo i sklupture (A) } \\
\hline Basle (dominikanski samostan) & Oko 1445 & $\mathrm{Ne}$ \\
\hline Basle (Klingenthal) & Oko 1475 & $\mathrm{Ne}$ \\
\hline Bern & $1516 / 20$ & $\mathrm{Ne}$ \\
\hline \multicolumn{3}{|l|}{ Manuskripti i knjige } \\
\hline Basle (Holbein) & 1525 & $\mathrm{Da}$ \\
\hline \multicolumn{3}{|l|}{ Velika Britanija } \\
\hline \multicolumn{3}{|l|}{ Zidno slikarstvo i sklupture (A) } \\
\hline London (St. Paul) & Oko 1430 & $\mathrm{Ne}$ \\
\hline \multicolumn{3}{|l|}{ Austrija } \\
\hline \multicolumn{3}{|l|}{ Zidno slikarstvo i sklupture (A) } \\
\hline Metnitz & Oko 1500 & $\mathrm{Da}$ \\
\hline \multicolumn{3}{|l|}{ Hrvatska } \\
\hline \multicolumn{3}{|l|}{ Zidno slikarstvo i skulpture (A) } \\
\hline Beram & 1474 & $\mathrm{Da}$ \\
\hline \multicolumn{3}{|l|}{ Slovenija } \\
\hline \multicolumn{3}{|l|}{ Zidno slikarstvo i skulpture (A) } \\
\hline Hrastovlje & 1490 & $\mathrm{Da}$ \\
\hline \multicolumn{3}{|l|}{ Italija } \\
\hline \multicolumn{3}{|l|}{ Zidno slikarstvo i skulpture (A) } \\
\hline Carisolo & 1519 & $\mathrm{Da}$ \\
\hline Pinzolo & 1539 & $\mathrm{Da}$ \\
\hline \multicolumn{3}{|l|}{ Španjolska } \\
\hline \multicolumn{3}{|l|}{ Manuskripti i knjige } \\
\hline Danza general de la muerte & Oko $1400 ?$ & $\mathrm{Da}$ \\
\hline
\end{tabular}


Pregled kasnosrednjovjekovnih prikaza plesa mrtvaca (Hammerstein, 1980) složen je po geografskom području, sukladno tomu kako ih je on popisao. (A) = zidno slikarstvo osim ako nije drugačije naznačeno. (B) = skulpture.

Prikazivanjem različitih staleških grupa i zanimanja, simultano su oslikavani društvena hijerarhija društva, vjerski aspekti, posljedice velikih kriza, ratova i epidemija kuge. Istraživanjima na različitim razinama: od likovno-umjetničkih do ikonografskih, preko proučavanja načina odijevanja (nošnje i moda tog doba) kao atributima neke klase, zatim proučavanja vrste glazbala ili pokreta plesa, te posrednih moralnih poruka koje sadrže freske plesa mrtvaca, dobivamo sliku srednjovjekovlja. Uklapanje takvih podataka u jedinstvenu cjelinu daje iscrpniji uvid u kulturni identitet nekog područja i neizmjerno veliku ulogu crkvenih redova, koji su kao naručitelji pojedinih djela zabilježili i očuvali nasljeđe različitih regija.

\section{Zaključak}

Bogatstvo različitih prikaza plesa mrtvaca očituje se kroz europsku povijest srednjeg vijeka, te oni spadaju u iznimno vrijednu likovnu baštinu. Materija koja obuhvaća temu plesa mrtvaca jedan je od primjera aktivne sinteze djelovanja crkvenih redova, lokalnog stanovništva i svekolikih zbivanja na različitim područjima Europe, ali i današnje Hrvatske. Povijesne informacije sadržane u arhivskim ili spomeničkim predmetnim odrednicama pružaju nam bolji pogled u razvojnu kronologiju plesa mrtvaca u Europi i Hrvatskoj, jer je tadašnje područje Hrvatske svojim razvojem pratilo europski kulturni krug. Zaštita kulturnih vrijednosti, muzeološka obrada, aktivna uloga crkvenih redova i lokalnog stanovništva u naše suvremeno doba bitni su za očuvanje spomeničke baštine kako u Europi, tako i u Hrvatskoj.

\section{Literatura:}

Achtman, Mark; Zurth, Kerstin; Morelli, Giovanna; Torrea, Gabriela; Goiyoule, Annie; Carniel, Elisabeth (1999). Yersinia pestis, the cause of plague, is a recently emerged clone of Yersinia pseudotuberculosis. PNAS, 96(24), 14043-14048.

Białostocki, Jan (1986). Povijest umjetnosti i humanističke znanosti. Zagreb: GZH.

Biblija = Adalbert Rebić, Jerko Fućak i Bonaventura Duda (ur.), Jeruzalemska Biblija s velikim komentarom. Zagreb: Kršćanska sadašnjost.

Blake, N. F. (1983). Dictionary of the Middle Ages. Vol.1. New York: Schribner.

Boccaccio, Giovanni (2004). Dekameron. Zagreb: Globus media.

Brandes, Stanley (1998). Iconography in Mexico's Day of the Dead: Orignis and Meaning. Berkeley: Duke University.

Dauber Jones, Constance (1979). Disease and Medicine in the Middle Ages. Laboratory Medicine, 10(1), 54-58.

Dunne, Michael (2007). A Being towards Death — the Vado mori. Maynooth Philosophical Papers, 4, 1-16.

Elder, Rozzanne (2013). Cistercian Writers: The Cambridge Companion to the Cistercian Order. Cambridge: Cambridge University. 
Espí Forcén, Carlos (2013). The Triumph of Death in Late Medieval Italian Painting. Journal of Humansitic Psychiatry, 1(2), 10-12.

Fein, David (2000). Guyot Marchant's Danse Macabre: The Relationship Between Image and Tekst. Helsinki: Mirator Elokuu.

Fučić, Branko (1992). Vincent iz Kastva. Zagreb: Kršćanska sadašnjost.

Haensch, Stephanie; Bianucci, Raffaella; Signoli, Michael; Rajerison, Minoarisoa; Schultz, Michael; Kacki, Sacha; Vrmunt, Marco; Weston, Darlene A.; Hurst, Derek; Achtman, Mark; Carniel, Elisabeth; Bramanti, Barbara (2010). Distinct Clones of Yersinia pestis Caused the Black Death. PLOS Pathogens, 6(10), e1001134. URL: https://www.ncbi.nlm.nih.gov/pmc/articles/PMC2951374/ (26.04.2018.)

Hammerstein, Reinhold (1980). Tanz und Musik des Todes. Die mittelalterlichen Totentänze und ihr Nachleben. Bern: Franke.

Huizinga, Johan (1930). Wege der Kulturgeschichte: Studien. München: Drei Masken.

Huizinga, Johan (1991). Jesen srednjeg vijeka. Zagreb: Naprijed.

Makenbach, Johan P. (1995). Social Inequality and Death as Illustrated in Late-Medieval Death Dances. American Journal of Public Health, 85(9), 1285-1292.

Ravančić, Gordan (2007). Historiografija o epidemiji Crne smrti s polovice 14. stoljeća. Povijesni prilozi, 33, 195-214.

Schulte, Brigitte (1990). Die deutschsprachigen spätmittelalterlichen Totentänze: Unter besonderer Berücksichtigung der Inkunabel "Des Dodes Dantz", Lübeck 1489. Wien: Böhlau Verlag.

Wheelis, Mark (2002). Biological Warfare at the 1346 Siege of Caffa. Emerging Infectious Diseases, 8(9), 971-975.

The Historiography of the Medieval Danse Macabre in the European Context

Mirela Lenkovic**

\section{Summary}

The Medieval Danse Macabre is depicted in many sacred buildings. Some of these works comprise an important part of the artistic legacy of Late-Medieval Europe. We may look upon the Danse Macabre as a form of artistic expression which symbolically unites the worldly and the religious and thematically puts forward the message of equality among people regardless of class. The Middle Ages are characterised by the cholera pandemic, adversity and war, all of which had an effect on cultural creativity. Various research (archeological, medical, etc.) explores the etiology of the Black Death, the development, history, appearance and spreading of the plague in Europe at that time. Certain literary works (De contemptu mundi; De miseria humane conditions Innocenta III.), artes morendi, memento mori (Hélinand de Froidmont, Les Vers de la Mort) avail themselves of Danse Macabre themes as a paradigm for artistic performances.

Key words: Medieval Period; iconography of death; plague in Europe; Danse Macabre

* Mirela Lenković, Doctorand at the University of Zagreb, Croatian Studies. Address: Borongajska cesta 83d, 10000 Zagreb, Croatia. E-mail: lenkovicmirela@gmail.com 